\title{
GURRENT GRISIS IN THE EU IN THE LIGHT OF THE CONTRADICTIONS OF THE CORE - PERIPHERY DEVELOPMENT MODEL
}

\section{Natalija Nikolovska (1), Daniela Mamucevska (2)}

(1) FullProfessor, "Ss. Cyril and Methodius" University in Skopje Faculty of Economics- Skopje, (2) Assistant Professor, "Ss. Cyril and Methodius"University in Skopje Faculty of Economics-Skopje

Natalija Nikolovska Ph.D. University in Skopje, Faculty of Economics Blvd. Goce Delchev 9v , 1000 Skopje, Macedonia natalijan@eccf.ukim.edu.m

Article info Paper category: Preliminary paper Received: 23.6.2015. Accepted: 28.09.2015. JEL classification: R11, R12, E63 


\begin{abstract}
This paper deals with the essential problems of the current economic crisis in the European Union analyzed from the aspect of the core - periphery development model. In the first part of the paper theoretical concepts are presented for explanation the reasons for divergence in the economic development among regions. In the second part of the paper special attention is given to the real convergence among the selected EU member countries. Regarding this, the paper arises the dilemma thus the stabilization programs, will be successful recipe for solving the problems of the current crisis.
\end{abstract}

\title{
Keywords:
}

regional policy, core and peryphery, territorial cohesion, monetary union, competitiveness 


\section{INTRODUCTION}

The focus of this paper is the phenomenon of the imbalanced regional development as a theoretical and practical problem and as a policy issue too. A number of theoretical studies are focused on the explanation of the phenomenon of the economic domination which in a most outstanding way it is presented in the growth poles theory of F. Perroux. Also, Karl Marx has given the most comprehensive analysis of the causalities for the regional imbalances as a phenomenon of the market and prices. The analytical and methodological devices of Marx's theory have served as a basis for distinctive approach of explanation of the regional development process from the prism of the theory for relationship between the core and periphery countries (i.e. regions). In the current economic circumstances this theory has a special role in the demystification of the tendencies in the modern regional development within the globalization processes.

Therefore, in this paper the core - periphery model will be used as a theoretical framework, in order to offer an alternative observation of the causes of the current economic crisis in the European Union. Actually, the main aim of the paper is to see the roots of the current account imbalances of European economies not as a "bad behavior" of the deficit countries but from the perspective of the development tendencies in the global economy. This analytical approach is in accordance with the need to explain why in the European area have been developed two different development strategies which generate different macroeconomic performances in the core and in the periphery countries. In fact, the core countries with weak domestic demand follow an export - led growth strategy, while the growth strategy in the periphery countries is based on the expansion of their domestic demand which is financed by the growth of the public debt. Both development strategies have been implemented within the single monetary policy with the same nominal interest rate for all countries, which as a feedback reinforces the appearance of these two opposite development strategies.

\section{THEORETICAL BACKGROUND: THE MARKET AND THE REGIONAL DISPARITIES}

Tendencies in a regional development show that growth does not appear in all places at the same time, with the same intensity and in the same mode. This empirical fact stimulated a number of distinguished economists to determine the forms of development (i.e. development vs underdevelopment), their causalities and as well as the potentials and possibilities of a regional policy. The most remarkable economist of the 1960s who animated the interest for the regional development was F. Perroux. His 'growth poles' theory gained a universal value and became a key tool for understanding the processes of the dynamics of territory considering the sequences 
of social and economic imbalances. Defining the analytical categories such as the dominant firm', 'the dominant market' and 'the dominant region', Perroux developed the concept of 'the domination effect in the economy' ${ }^{1}$. The effects of domination arise when some regions are not in a position to oppose to asymmetric activities and influences from the other regions. The phenomenon of domination is present not only in economic interaction among branches within a certain economic area but also in economic relations between regions within the state and among national states in the global system. Regarding the 'growth poles' theory, the hierarchical power of the dominant units in the system arises from three sources: economy of scale, externalities and economies of agglomeration. So, the positivism in the Perroux's theory is found in the conclusion that the 'growth pole' has a high market and competitive potential and as a magnet attracts the production resources, and in the same time it is capable to induce the growth in the neighboring (less developed) regions. But, confronting this theoretical concept one dilemma came up: 'Does the pole support the growth in the less developed regions or the accumulated propulsive economic structure of the pole is the ultimate determinant for exhaustion of the periphery?' Even today the answer of this question occupies the academic community.

The modern crises have multiplied confrontations among the developed and undeveloped parts at the all levels of the global system and in that context they have turned the attention to the regional imbalances. The question about the role of market in the income distribution and widening of the gap in development among different regions has become popular again. The current European economic crisis might be analyzed from this perspective. So, for more essential explanation of the processes we will consider the opinions about the role of market and regional development of the opposite groups of theoreticians.

The first group of theoreticians considers that the global market is sufficient mechanism for inducing development in undeveloped regions. Actually, this is a dominant stance in the official policies of the global institutions (International Monetary Fund and World Bank). These theoreticians as an empirical example show the experience of those countries which have overcome the poverty threshold by using of their traditional economic relations they increased the share in the global export of agricultural and raw products and realized high growth rates. Consequently, the export diversification is the next phase in the economic development of these countries. This theoretical optimism has roots in the classical economics which developed the concepts for absolute and comparative advantages to explain international exchange among countries. The modern neoclassical economics upgraded the concepts of absolute and comparative advantages into the Heckscher-Ohlin new trade theory. The principle of comparative costs is transformed into the general theory of

1 The thesis for 'domination effect in the economy' Perroux had explained in three separate articles published in 1948, 1949 and 1950. Then, these articles were republished in his remarkable book "L'economie du XXe siècle" Presses universitaires de France, Paris, 1961 (chapters 2, 3 and 12). 
international value where the inverse demand is its substantial part. Ohlin used term 'region' (not the term 'state') with free movement of the production factors within the region. Due to the unequal factors endowments among the regions, there are differences in the level of their production costs. Production specialization of the regions in terms of their ample factors will equalize the prices of production factors and this will remove the differences in the level of production costs, and consequently will decrease the development gap among the regions.

Another group of theoreticians support the thesis that increasing the differences between the countries and regions is a cumulative process immanent for the market mechanism. Maybe the most consistent concept for analysis of the regional disparities is one offered by the Marxian political economy. The main hypotheses of the Marxian analysis are: (i) all destructive tendencies as a consequence of the competition process within one country are multiply on the world market (Marx,1946: 193-184); (ii) if one country has more developed capitalistic production, then its labour productivity is higher and it is above the level of average international productivity. Different quantities of the same type of goods, which are produced in different countries for the same time units, have different international value and different prices respectively (Marx,1947: 489-490); (iii) In the international trade, the more developed countries are selling their goods for prices which are higher than their internal value, besides the fact that they might be cheaper than the goods produced in the competitive countries. This is a mechanism for valuation of the labour of developed countries in the international trade (Marx , 1948): 190)).

The Marxian analysis gave strong theoretical basis for his adherents for studying the actual spatial contradictions in the global economy. The complex interdependence of the modern regional differences is an issue that is actualized by the core-periphery theory, which analysis is based on the Marxian methodology. The key principles of the core-periphery theory are based on the following conclusions (Nikolovska, 2000):

- Economic development and economic un-development are two sides of the same model. Both processes are product from the inner contradictions of the modern capitalistic development. It is not a question of variety in efficiency of different types of socio-economic systems or to the attained level of development of society, but it is a question of the 'contradictions in the economic structure of development of global capitalism'.

- Capitalism has developed into the dominant form of socio - economic system in the world. Monopoly position of the core countries gives possibilities to these countries for appropriation of the added value created in the periphery countries and to use it for their own economic development.

- The mechanism of appropriation of the new added value is based on the production prices, which are in favor of the branches of the economy that have higher substantial value of the production factors. Consequently, the unbal- 
anced spatial distribution of the branches creates an uneven development of the regions (and countries). Hence, discriminatory practice toward undeveloped regions and states are created and it is a product of the monopoly position of the leaders countries in the field of technology and development. Elements of technological progress which are located in the core regions (countries) are the main factor for growth of their productivity above the average value. This will result in the internalization of the external costs in the global economy.

- Redistribution of financial resources through the financial markets in the favor of the developed (core) countries. In the era of domination of financial capital, modern economic reforms in the periphery countries are characterized as monetary schemes for stabilization and structural adjustment of their economies with finial outcome - contraction of domestic production and development of consumer markets as a part of the global market. The international institutional network (FED, World Bank, International Monetary Fund, European Central Bank) supports the monetary liquidity. Hence, the financial assets grow faster than the entrepreneurship (investment in production). This lead to cost inflation accompanied with the growth of unemployment. As a result of the financial alchemy (or creation of virtual wealth) there is a process of redistribution of the financial resources among the countries with deep and developed financial markets and the ones in the periphery countries. Precisely, the core countries extract the accumulation from periphery countries by the use of their capital and goods markets, and on that way deepening the gap in development among them.

Also, these inferences are in accordance with Krugman (1991) and his concept about 'new economic geography' which unambiguously suggests formation of core-periphery development model based on the principle of increasing returns and decreasing costs. Bearers of the 'new economic divide' are the transnational corporations (TNCs), which are almost not present in the economies of developing countries. However, considering Porter's findings, the absence of TNCs in one country is a strong barrier for formation of its national diamond for comparative advantages, and the country get stick in the position of 'factor driven economy' with imbalanced model of development. Horn et al. (2009) and Stockhammer (2010) and (2011) analyzed different models of development in the European economy from the perspective of the current crisis, and they pointed out on the relevance of the core -periphery development model. In a nutshell, the core-periphery theory demystifies the modern contradictions in the economic development regarding developed and undeveloped countries. It confronts with the thesis of western theoreticians who treat the center (the pole) of growth as a mode of growth dispersion. In this manner, the coreperiphery theory offers an analytical explanation of the tendencies of polarization in the modern regional development. 


\section{EMPIRICAL ANALYSIS: THE CRISIS IN THE EU AS A REFLECTION OF THE CORE-PERIPHERY MODEL}

The key idea of this paper is the crisis in the EU does not analyze from the perspective of mistakes of the endogenous economic policy of the countries affected by the crisis, but from the prism of the core-periphery development model. For this purpose it will be analyzed the group of countries EU-1 $15^{2}$. Regarding their performances the countries are divided into two groups. First group is the group of core countries: Germany, Austria, Belgium, Denmark, Finland, France, Netherlands, Sweden, United Kingdom; and the second group are periphery countries: Greece, Ireland, Italy, Portugal and Spain.

Taking into consideration the premise of core-periphery model about uneven (imbalanced) economic development, deficits in the periphery countries and surpluses in the countries from the core are treated as a product of the same phenomenon. The core-periphery model is confronting with the strategic goal of the European Union. The real convergence, as a strategic goal of the EU, was defined since the beginning of the process of the union's formation. The European Union was striving for balanced development as an economic and social value and it was realizing through the convergence of the GDP per capita and the rate of employment. But this goal fell into the shadow on the latest trends and developments in the EU.

In practice, the monetary strategy and the liberal market have resulted in two different models of development and in that context there are two different development strategies for the countries on a different level of economic development (core countries vs periphery countries). However, the both strategies are mutually connected, i.e. the growth in the core countries is corresponding to the consumption in the periphery countries, while the latter ones have a necessity for the financial funds of the core in order to maintain their current account deficits (Uho, et al. 2011: $57^{3}$ ).

The heterogeneity of the member countries of the EU is undeniable fact. The opportunity for realization of higher and sustainable rates of economic growth within the globalized European economy is directly depended from the ability of the member countries of the EU to mobilize their resources in the promotion of the export-oriented growth model by which the capital should be accumulated. However, the export orientation is an aim of the European development strategy as a whole, and within the "strategic navigation" (Maastricht criteria) it was transformed in the core - periphery development model in accordance to the previously acquired comparative advantages of the countries. History, again, confirmed the experience of accumulation on imbalances in the economic development by using this model as a basis for creation of the development strategy. In fact, development process of the European area was split on two developmental strategies which are two sides of the same phenomenon - "the con-

2 EU15: Austria, Belgium, Denmark, Finland, France, Germany, Netherlands, Sweden, United Kingdom, Greece, Ireland, Italy, Portugal and Spain. 
tradiction of development in the economic structure in capitalistic society". Different strategies of development are product of restructuring of the Euroland in anticipation of the competition on the global market. Different levels of countries' development are consequence from the process of the real divergence between the performances of the core countries and the periphery ones in the EU. The real divergence is due to the fact that the capital is accumulating in the core countries, and the debt is accumulating in the countries from the periphery. A debt accumulation in the periphery countries is a result from the tendency of losing of the competitiveness of these economies and it became a factor for their unstable economic growth.

Performances of the model of development of core countries can be analyzed on the case of German economy as a representative of the export-oriented strategy. This strategy is used as a base for increasing of the economy's competitiveness on the global market. Actually, in the last decade the accent has been put on the restrictive income policy regarding the nominal inflation target and the productivity growth. Such policy has resulted into the low growth of the per unit labor costs. Changes in the income distribution towards the saving of labor costs have decreased the private consumption in the German economy. Higher profits did not increase the dynamics of investments in the capital stock, but they have turned money toward the nonfinancial institutions. These institutions invested free funds in the countries from the periphery where the increased demand met with the increased offer of the competitive goods from the European core. Competitiveness of the German economy is obvious. For instance, the value of the exported German goods in 2005 was $76 \%$ higher compared with their value in 2000. In 2007, at the outbreak of the crisis, the value of the exported goods was $24,0,03$ percent of that of 2000. In the same period the value of the imported goods was increasing with slower dynamics due to the decreasing of domestic demand (see Table 1.).

Table 1.: Export value index and Import value index for EU-15; $(2000=100)$

\begin{tabular}{|c|c|c|c|c|c|c|}
\hline & \multicolumn{2}{|c|}{2005} & \multicolumn{2}{|c|}{2007} & \multicolumn{2}{|c|}{2013} \\
\hline & $\begin{array}{c}\text { export } \\
\text { index }\end{array}$ & $\begin{array}{c}\text { import } \\
\text { index }\end{array}$ & $\begin{array}{c}\text { export } \\
\text { index }\end{array}$ & $\begin{array}{c}\text { import } \\
\text { index }\end{array}$ & $\begin{array}{c}\text { export } \\
\text { index }\end{array}$ & $\begin{array}{c}\text { import } \\
\text { index }\end{array}$ \\
\hline \multicolumn{7}{|l|}{$\begin{array}{l}\text { Core } \\
\text { countries }\end{array}$} \\
\hline Austria & 185,34 & 176,32 & $24,2,25$ & 225,77 & $25^{8,07}$ & 252,39 \\
\hline Belgium & 177,96 & 179,98 & 229,34 & $232,4,2$ & $249,5^{\circ}$ & $254,3 \circ$ \\
\hline Denmark & 166,36 & 166,31 & 201,64 & 215,71 & $2,17,5^{2}$ & 213,92 \\
\hline Finland & $142,4,2$ & 171,04 & 195,75 & 237,80 & 161,24 & 224,84 \\
\hline France & 141,81 & 149,10 & 171,24 & 186,59 & 177,37 & 201,32 \\
\hline Germany & 176,39 & 156,68 & $24,0,03$ & 212,71 & $263,9^{3}$ & 239,38 \\
\hline Luxemburg & 224,92 & 194,60 & 267,92 & 245,02 & 232,86 & 239,68 \\
\hline Netherlands & 174,74 & 167,10 & $2,36,83$ & 226,25 & 285,32 & 271,11 \\
\hline Sweden & 150,67 & $15^{3,64}$ & 194,23 & 210,77 & 192,71 & 217,84 \\
\hline
\end{tabular}




\begin{tabular}{|l|c|c|c|c|c|c|}
\hline & \multicolumn{2}{|c|}{2005} & \multicolumn{2}{|c|}{2007} & \multicolumn{2}{|c|}{2013} \\
\hline United & 135,04 & 147,95 & 154,22 & 179,42 & 190,13 & 188,49 \\
Kingdom & & & & & & \\
Periphery & & & & & & \\
countries & & & & & & \\
Greece & 147,41 & 163,00 & 201,15 & 235,15 & 311,33 & 186,11 \\
Ireland & 142,00 & 134,67 & 157,39 & 164,63 & 147,87 & 127,88 \\
Italy & 155,14 & 161,16 & 207,84 & 214,30 & 215,23 & 199,91 \\
Portugal & 156,97 & 153,52 & 216,03 & 206,08 & 258,70 & 188,67 \\
Spain & 167,57 & 185,41 & 220,32 & 249,94 & 274,44 & 217,55 \\
\hline
\end{tabular}

Source: World Bank database.

In the period from 2000 to 2013 in the most of the core countries the value of the export value index is higher than the value of the import value index. In the same period, in the most of the periphery countries the value of the import value index is higher than the value of the export value index, which indicates for less competitive power of their economies. At the outbreak of the crisis, almost all analyzed countries registered higher value of the import value index compared with the export value index.

Figure 1.: The annual average growth rate of GDP for the core countries and periphery COUNTRIES IN the period $2000-2013$

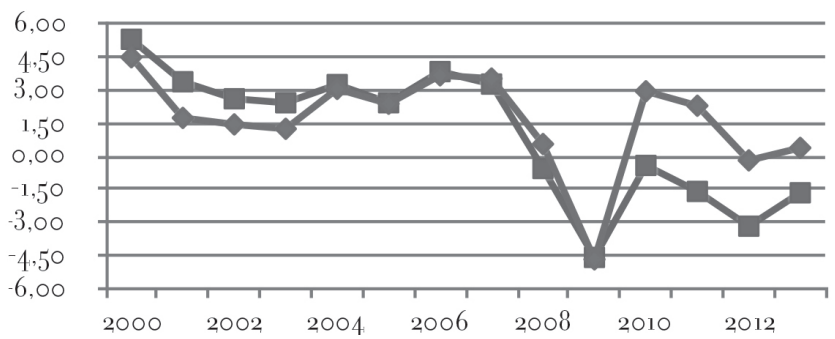

Core countires

를 Periphery countires

Source: Authors' calculation based on the data from World Bank database.

Before the outbreak of the crisis, the growth rate of GDP of the periphery countries was higher than the one of core countries. However, after 2009 the core countries had modest positive growth rate of GDP and the counters from the periphery realized negative trends in their GDP growth rate (Figure 1). Besides these positive trends in the international trade German economy has realized anemic economic growth. In the period (2000-2006) the average annual growth rate of GDP was e $(1.37 \%)$ and $(0.98 \%)$ during the period $2007^{-2013}$. In the periphery countries the positive values of GDP growth rate has converted into negative rates (see Table 2.). These variations are due to different sources of economy development. Economic growth in the periphery countries is not based on the sound fundaments (i.e. own capital accumulation). 
Table 2.: Average annual growth rate of GDP for the periods: 2000-2006 and 2007-2013

\begin{tabular}{|l|r|r|}
\hline & 2000-2006 & 2007-2013 \\
\hline Core cuntires: & & \\
Austria & 2,19 & 1,06 \\
Belgium & 2,13 & 0,83 \\
Denmark & 2,04 & $-0,48$ \\
Germany & 1,37 & 0,98 \\
France & 2,08 & 0,64 \\
Finland & 3,24 & 0,06 \\
Luxemburg & 4,12 & 1,60 \\
Netherlands & 2,02 & 0,49 \\
Sweden & 3,23 & 1,04 \\
United Kingdom & 3,07 & 0,54 \\
Periphery cuntires & & \\
Greece & 4,17 & $-3,73$ \\
Ireland & 5,62 & $-0,24$ \\
Italy & 1,49 & $-1,03$ \\
Spain & 3,77 & $-0,37$ \\
Portugal & 1,39 & $-0,84$ \\
\hline
\end{tabular}

Source: Authors' calculation based on the data from World Bank database.

For instance, it has been based on the inflow of external capital, increasing debts of private and public sectors, while the main source of the growth is consumption of these sectors. Private and public consumption might be realized in the form of investments in production, but in the latter phases this model is followed by decline of the growth of gross domestic product because the biggest part of the consumption is satisfied with the imported goods and increasing the debts of countries.

During the last decade, in the periphery countries the so called "investment in production" has been realized through the expansion of the construction sector. Demand in the construction sector had stimulated the increase in prices which was followed with less dynamic increasing in wages. Deficit in consumption was financed with credit expansion. Created preconditions with Maastricht criteria (decreasing of interest rates, eliminating the premium for foreign exchange risk and price stabilization) had developed favorable environment for credit expansion. In the context of the recovery of business cycle, the credit expansion through the construction sector stimulated formation of speculative bubble with the prices on real estate markets. So, the common monetary policy (which is focused on stable prices and low interest rates) had different consequences for heterogeneous countries regarding their level of economic development. In the core countries monetary policy has had a stabilizing effect and it was creating preconditions for export-oriented growth, whereas in the periphery countries this policy was an initiator for destabilization of their economies 
and it has increased the divergence in the flows of real sectors through accumulating a numerous imbalances, especially the one in their current accounts (see Table 3.).

Table 3. : Current account as a percentage of GDP

\begin{tabular}{|c|c|c|c|c|c|c|c|c|c|c|c|}
\hline & 2001 & 2004 & 2005 & 2006 & 2007 & 2008 & 2009 & 2010 & 2011 & 2012 & 2013 \\
\hline \multicolumn{12}{|l|}{$\begin{array}{l}\text { Core } \\
\text { countries }\end{array}$} \\
\hline Austria & $-0,8$ & 2,1 & 2,1 & 2,7 & 3,3 & 4,7 & 2,6 & 3,3 & 1,6 & 1,8 & 2,6 \\
\hline Belgium & 3,3 & 3,2 & 2 & 1,8 & 2 & $-1,1$ & $-0,8$ & 1,8 & $-1,2$ & -2 & $-1,9$ \\
\hline Denmark & 2,5 & 2,2 & 4,2 & 2,9 & 1,3 & 2,6 & 3,3 & 5,8 & 5,5 & 5,6 & 7,2 \\
\hline Finland & 8,1 & 5,9 & 3,2 & 4 & 4,1 & 2,5 & 1,7 & 1,4 & $-1,4$ & $-1,4$ & -1 \\
\hline France & 1,7 & 0,5 & $-0,5$ & $-0,6$ & -1 & $-1,7$ & $-1,3$ & $-1,3$ & $-1,7$ & $-2,1$ & $-1,3$ \\
\hline Germany & $\circ$ & 4,4 & 4,8 & 6 & 7,2 & 6 & 5,7 & 6 & 6,6 & 7,3 & 7,4 \\
\hline Luxembourg & 8,4 & 12,1 & 11,8 & 10,4 & 10,4 & 5,3 & 6,8 & 7,8 & 6,7 & 6 & 5,5 \\
\hline Netherlands & 2,4 & 7,2 & 7 & 8,7 & 6,3 & 4 & 4,8 & 6,8 & 8,5 & 8,9 & 10,1 \\
\hline Sweden & 4,7 & 6,3 & 6,5 & 8,2 & 8,9 & 8,6 & 5,9 & 6 & 5,8 & 5,8 & 6,6 \\
\hline $\begin{array}{l}\text { United } \\
\text { Kingdom }\end{array}$ & $-2,2$ & $-1,9$ & $-1,8$ & $-2,7$ & $-2,1$ & $-0,9$ & $-1,4$ & $-2,6$ & $-1,4$ & $-3,6$ & $-4,2$ \\
\hline \multicolumn{12}{|l|}{$\begin{array}{l}\text { Periphery } \\
\text { countries }\end{array}$} \\
\hline Greece & $-6,8$ & $-5,4$ & $-7,3$ & $-10,9$ & -14 & $-14,4$ & $-10,8$ & $-9,4$ & -10 & $-2,6$ & 1,2 \\
\hline Ireland & $-0,6$ & $-0,6$ & $-3,4$ & $-3,5$ & $-5,2$ & $-5,4$ & $-2,2$ & 1,1 & 1,2 & 4,2 & 6,2 \\
\hline Italy & $-0,1$ & $-0,9$ & $-1,6$ & $-2,5$ & $-2,3$ & $-2,8$ & $-1,8$ & $-3,3$ & $-2,9$ & $-0,2$ & 1 \\
\hline Portugal & $-10,2$ & $-8,1$ & -10 & $-10,1$ & $-9,7$ & $-12,2$ & $-10,5$ & $-10,2$ & $-6,8$ & -2 & 0,5 \\
\hline
\end{tabular}

Source: OECD database.

In addition, creation of the European Monetary Union, liberalization and financial deregulation supported an increase in deficit in the current accounts of the countries from the periphery. These processes created an environment for easy mobilization of free financial accumulation from the core countries. The most part of accumulated financial resources have been invested into periphery countries and they served as means of financing of their increased public and private consumption. Actually, from one side, these ways of the financial flows were a direct consequence from the structural imbalances among the economies from core and periphery of the Eurozone and from the other side these financial flows reflected the innate motives for circulation of financial innovations on markets where credits and credit risk were traded with higher earnings. In this context, markets in the periphery were used for placement of goods, services and credits portfolios of the core countries. The outcome of this situation was capital accumulation in the core countries and accumulation of deficit, debt and losses in the periphery counties. Increased private and public debts in the countries confirmed that in the new financial setting speculative financial activities were preferred than investment in the productive projects. For instance, in 
Ireland in a very short period of time, debts of households and nonfinancial corporations increased from $171,2 \%$ of GDP in 2005 to $281,5 \%$ of GDP in 2012, (see Table 5.). Corresponding with these trends the government debt increased too (see Table 4.). Process of speculative growth of indebted periphery economies was broken by the financial crisis in the USA, contraction of the boom-bust financial cycle and by the external shocks in the real sector (for example, rising oil prices). Transmission of the external shocks through the finance and trade has stressed out the conflict between the core and periphery countries of EU in the form of a financial crisis and a crisis of the public debt.

Table 4.: Central government debt (total) as a percentage of GDP

\begin{tabular}{|l|r|r|r|r|r|r|r|r|r|}
\hline & $\mathbf{2 0 0 0}$ & $\mathbf{2 0 0 5}$ & $\mathbf{2 0 0 6}$ & $\mathbf{2 0 0 7}$ & $\mathbf{2 0 0 8}$ & $\mathbf{2 0 0 9}$ & $\mathbf{2 0 1 0}$ & $\mathbf{2 0 1 1}$ & $\mathbf{2 0 1 2}$ \\
\hline Core & & & & & & & & & \\
countries & & & & & & & & & \\
Austria & 64,13 & 65,43 & 62,04 & 59,01 & 64,14 & 68,99 & 72,17 & 73,12 & 78,46 \\
Belgium & $104,5^{3}$ & 87,03 & 83,21 & 80,21 & 82,70 & 87,00 & 86,24 & 88,57 & 89,44 \\
Denmark & 51,93 & 35,71 & 31,97 & 24,14 & 30,79 & 37,03 & 41,24 & 47,97 & 47,23 \\
Finland & 55,22 & 42,24 & 39,69 & 36,01 & 31,97 & 41,24 & 47,00 & 45,96 & 51,00 \\
France & 59,59 & 70,70 & 66,46 & 65,38 & 71,00 & 82,69 & 86,46 & 90,60 & 100,85 \\
Germany & 38,28 & 43,30 & 42,10 & 39,43 & 41,73 & 46,04 & 53,74 & 53,32 & 55,18 \\
Luxemburg & n.a. & 3,67 & 4,34 & 4,78 & 12,33 & 13,29 & 17,51 & 16,92 & 20,03 \\
Netherlands & 48,50 & 48,89 & 43,16 & $4,0,58$ & 52,11 & 53,94 & 57,66 & 61,79 & 67,89 \\
Sweden & 64,91 & 50,57 & 44,25 & 38,64 & 39,74 & 39,72 & 36,68 & 36,66 & 35,29 \\
United & 43,31 & 43,92 & 43,78 & 44,78 & 54,35 & 68,60 & 81,18 & 94,58 & 97,17 \\
Kingdom & & & & & & & & & \\
Periphery & & & & & & & & & \\
countries & & & & & & & & & \\
Greece & 119,15 & 121,56 & 123,04 & 120,39 & 116,81 & 133,25 & 126,93 & 108,70 & 163,56 \\
Ireland & 39,34 & 31,78 & 28,19 & 27,63 & 46,84 & 66,94 & 83,70 & 97,80 & 120,46 \\
Italy & 114,70 & 108,71 & 105,13 & 100,62 & 103,40 & 117,12 & 115,85 & 108,90 & 126,16 \\
Spain & 53,28 & 37,69 & 33,37 & 29,44 & 33,53 & 45,56 & 47,10 & 54,59 & 65,92 \\
Portugal & 64,91 & 50,57 & 44,25 & 38,64 & 39,74 & 39,72 & 36,68 & 36,66 & 35,29 \\
\hline
\end{tabular}

Source: EUROSTAT database. 
Table 5.: Private sector debt, consolidated a percentage of GDP

\begin{tabular}{|l|r|r|r|r|r|r|r|r|r|r|}
\hline & $\mathbf{2 0 0 0}$ & $\mathbf{2 0 0 5}$ & $\mathbf{2 0 0 6}$ & $\mathbf{2 0 0 7}$ & $\mathbf{2 0 0 8}$ & $\mathbf{2 0 0 9}$ & $\mathbf{2 0 1 0}$ & $\mathbf{2 0 1 1}$ & $\mathbf{2 0 1 2}$ & $\mathbf{2 0 1 3}$ \\
\hline Core & & & & & & & & & & \\
countries & & & & & & & & & & \\
Austria & 121,7 & 124 & 122,9 & 124,6 & 127,5 & 132,8 & 133,1 & 130 & 128,3 & 126,9 \\
Belgium & 114,2 & 119,5 & 119,8 & 134,4 & 162,9 & 165,3 & 161,9 & 174,5 & 180,5 & 175,8 \\
Denmark & 158,1 & 187,7 & 199,9 & 208,4 & 222,8 & 233,3 & 222,1 & 222,6 & 226,6 & 224,1 \\
Germany & 123 & 117,1 & 114,1 & 111 & 109,3 & 113,4 & 107,7 & 103,9 & 103,7 & 103,5 \\
France & 99 & 109,2 & 112,6 & 115,6 & 122,2 & 130,5 & 131,8 & 135,3 & 138,2 & 137,3 \\
Luxemburg & n.a. & n.a. & n.a. & n.a. & 391,4 & 421,8 & $34,8,1$ & 347,3 & $34,0,6$ & 356,2 \\
Netherlands & 206,2 & 217,7 & 217,7 & 216,8 & 217,3 & 231,4 & 229,4 & 228 & 230,2 & 229,7 \\
Finland & 91,9 & 114,7 & 117,9 & 122,3 & 131,3 & $14,1,3$ & 145,8 & $14,2,4$ & $14,6,6$ & $14,6,2$ \\
Sweden & $14,1,7$ & 159,2 & 161,2 & 177,6 & 200,1 & 212,6 & 200,8 & 200,4 & 202,4 & 200,1 \\
United & 138,5 & 168,4 & 174,3 & 176,8 & 186,1 & 189,9 & 177 & 173,5 & 175,8 & 164,4 \\
Kingdom & & & & & & & & & & \\
Periphery & & & & & & & & & & \\
countries & & & & & & & & & & \\
Ireland & n.a. & 171,2 & 191,7 & 198,1 & 237,4 & 258,5 & 261,2 & 277,9 & 281,5 & 270,3 \\
Greece & 53,1 & 86,2 & 93 & 101,9 & 113,5 & 117,2 & 128,8 & 130,6 & 130,5 & 135,6 \\
Spain & 102,9 & 154,9 & 177,8 & 191,9 & 196,6 & 202,4 & 201,5 & 195,3 & 184,8 & 172,2 \\
Portugal & 137,1 & 171,4 & 176,5 & 185 & 196,2 & 204,2 & 201,5 & 204,1 & 209,6 & 202,6 \\
Italy & 75,8 & 95,9 & 102,2 & 109,6 & 113,7 & 120,1 & 121,2 & 120,4 & 121,7 & 119,5 \\
\hline
\end{tabular}

Source: EUROSTAT database.

Hence, realization of the strategic goals of the European Union emphasizes the actual position of the core countries as a dynamic pole of growth. In that context, successful completion of the EU's development agenda 2020 is directly determined of the speed and effectiveness of the post crisis economic recovery in the periphery countries. Therefore, stabilization policy is becoming a priority, and it will determine the future perspectives of development and further integration of the European Union.

\section{Current response to the crisis: stabilization vis a vi convergence}

In a nutshell, we may note that the European integration is a process characterized with innate contradictions. A scientific and technological progress in the European Union is stimulated by the amplification of the competition on the global market. This process increases the role and significance of the core countries in the European Union as a main engine of its development. In this context, the regional policy should enable periphery countries to follow the dynamics of development of the core ones. But the current economic crisis in the EU has highlighted the contradictions in the integration process. The financial resources have become more and 
more scarce input for development. The reformation of the regional policy with the Lisbon strategy has stresses the priority for the Union to develop the propulsive export strategies which are in accordance with the acquired competitive advantages of its core countries. In order the core counties to keep the pace of high developmental dynamics as soon as possible the periphery countries should overcome the negative effects from the economic crisis. Thus, in this moment the stabilization policies are in the priority lists of the EU's agenda. In the September 2012, European Stability Mechanism (ECM) was created. It is an international organization with main purpose to safeguard the eurozone and to provide instant access to financial programs for its member states with financial difficulties. The access to the financial programs is conditional with the implementation of the rigid programs for economic and financial adjustment and sustainability of the public debt of the financially distressed member state. The maximum lending capacity of the ECM is 500 billion Euro and it replaced the earlier temporary EU funding programs European Financial Stability Facility (EFSF) and European Financial Stabilization Mechanism (EFSM). At the beginning of 2015 , The European Commission created the so called Juncker investment plan (of cca $31_{5}$ billion EURO) to deal with the virtuous triangle: to mobilize investment finance without creating public debt; to support investments in key sectors (infrastructure, education and research and innovation); and to remove financial and non-financial barriers to investment. But actually, the main purpose of the financial injection is capitalization of banks and to support the real sector as a way to stabilize the banking system, to improve expectations regarding the region's stability and to increase the marginal efficiency of capital. All these activities should result in consolidation of the distressed European monetary system.

However, the creation of new mechanisms and financial programs for liquidity support of the periphery countries have emphasized more problems and dilemmas, such as:

- The new dynamics of injection of monetary liquidity will stimulate faster monetary growth regarding financial resources, while the growth rate of production will continually decrease. These conditions will intensify the inflation tendencies in the economies. The monetary schemes will be use to compress the cost inflation which will result in deflation tendencies in production, consumption and unemployment in the periphery countries;

- -Financial rescue packages is a mode for redistribution of the capital among financial markets (surplus-capital countries) and consumer markets (deficit-capital countries). So, the modern global capitalism creates money with which it revitalizes the speculative financial markets and increases the gap between the core and periphery countries.

- After the crisis, the gap in the economic performances between the core and periphery countries is increasing, which is due to the capital redistribution among the countries with capital surplus and deficit ones. As a result, the role 
of the core countries has transformed from the position of the 'importer of the last resort' into the 'capital exporter of the first resort' (in order to finance the import of their goods in the periphery countries) on the one hand, and into 'capital exporter of the last resort' (for implementation of stabilization packages to save the periphery economies as a market for their goods) on the other hand.

- Consequently, the main dilemma is about the current rule of a European cohesion policy and thus this policy, still has the potential to be the main component of the development strategy of the EU.

\section{CONCLUSION}

In the public and professional debates, elaborations about the causes of the current crisis are situated between coordinates on the lack of fiscal discipline and the lack of structural reforms in terms of improvement of the competitiveness of an economy. However, the key idea of this paper is that the economic crisis in the European Union should be analyzed from the perspective of the persistent increasing macroeconomic imbalances (e.g. current account deficits and public debts) which are result from the different growth models that were developed within the process of creation of the euro currency. These processes were causal consequence from the increasing globalization of the European economy and they were amplifying the classical regional dichotomy of the core and periphery countries.

The main engine in the global race for transnationalization of the European economy is governed by the core countries (for instance German economy) while the periphery countries in this race are marginalized (they are losing their competitiveness and are accumulating debts). As our empirical analysis suggests, the positive growth performances of the core countries are realized through the markets and deficits of the periphery countries. In fact, this is the way for globalization and corporatization of European economy in order to strengthen its competitiveness for better performances in the competition race with other developed parts of the world economy.

Functional integration (i.e. market integration) of European economy makes less relevant the standard models of international trade theories concerning the development of international competitiveness, especially in surroundings where the processes of mergers and acquisitions among the big businesses is reinforced. The leaders of these processes in the EU are the core countries led by the German economy.

However, this model of development creates conflicts between the goal of managing the increasing gap in macroeconomic performances of the national economies and improving the functional market integration of the European economy. Creation of the European monetary union and financial integration has a key role in explain- 
ing the rising of current account deficits to historically unknown level: the risk premium has disappeared and the easier access to funding was ensured.

The great recession has faced with the fact that financing the excess of demand through the borrowing of the periphery countries is not sustainable and it leads to destabilization of the European Union. Juncker investment plan is an attempt to establish an agent who will stimulate the aggregate demand within the framework of the established stabilization schemes for financial markets. Actually, these financial schemes are aimed to save the interests of creditors and to help them to consolidate the economic relations between export oriented and import oriented countries (i.e. between core and periphery economies).

However, to solve these problems it is necessary for faster growth of domestic demand in countries that have implemented the export based growth model. And thus, to make this possible it is necessary to change the pattern of income distribution and the wage restriction policy which are applied in core countries (like the case in Germany). So, consequently the Maastricht nominal criteria should be substituted with the new more complex development paradigms which implementation will result in more balanced macroeconomic performances within the European economy. 


\section{REFERENCES}

Arestis Philip and Malcom Sawyer, "The Design Faults of the Economic and Monetary Union", Journal of Contemporary Economic Studies, 19 no.1, (2011): 21-32

Baldwin R. and Wyplosz C., The economics of European Integration, (McGraw-Hill, 2009)

Barca Fabrizio, "An Agenda for a Reformed Cohesion Policy - A Place-based approach to meet European Union Challenges and Expectations", Independent Report prepared on request of Dabnuta Hubner Commissioner for regional policy, April, (2009)

Begg I. and J.Bergman, "Introduction: EU social (exclusion) policy revisited", Journal of European Social Policy, No 12, (2002): 179-196

Commission of the European Communities, "Elements for a Common Strategic Framework 2014-2020", Commission staff working document, Part 1, March (2012)

Commission of the European Communities, "Regions Delivering innovations through Cohesion policy", Commission staff working paper, Brussels, (2007)

De Grauwe Paul, "The Convergence of a Fragile Eurozone", The Centre for European Policy Studies,Working Document, No.346, (2011)

De Grauwe, P. and Schnable, G,"Nominal versus real convergence with respect to EMU accession", European University Institute Working Papers, RSCAS No2o, available at: http:/www.eui.eu/RSCAS/WPTexts/o4_20.pdf, (2004)

European Commission, "Cohesion policy and The Environment", EU Publication Offices, September, (2010)

European Commission, "Surveillance of Intra Euro-Area Competitiveness and Imbalances", Discussion paper, (2010a)

European Commission, "The EU's Comprehensive Policy Response to the crisis", Special issues, Quarterly report on the Euro Area, 10 no1, (2011), 7-14

European Commission, "The Impact of the Global Crisis on Competitiveness and Current Account Divergences in the Euro Area", Special issues, Quarterly report on the Euro Area, 9 no1, (2O10b), 1-42

Harvey Armstrong and Taylor Jim, "Regional Economics and Policy", Blackwell Publishing, UK, (2000)

Horn G, Dröge K., Sturn S., T. van Treeck and Zwiener R., "From the financial crisis to the world economic crisis. The role of inequality", Dusseldorf: Macroeconomic Policy Institute report 41, (2009)

Komarovsky V. and Bondaruk V., "The role of the concept of "Growth poles" for regional development", Journal of Public Administration, Finance and Law, Issue 4, (2013): 31-42,

Krugman P, "Increasing returns and economic geography", Journal of Political Economy, vol.(99) No.3, (1991): 483-499

Marx Karl, Capital I, translation (Zagreb, 1947)

Marx Karl, Capital III, translation (Belgrade, 1948)

Molle Willem, The European Cohesion Policy, (UK, Routledge, 2007)

Ognjen Maric, "The Regional Policy of European Union as an Engine of Economic Development", European movement in Serbia, April, (2010) 
Natalija Nikolovska, "Regionalna Ekonomija", (Skopje, UKIM-Ekonomski Fakultet- Skopje, 200o)

SchmidtA. Vivien, "The Future of European Capitalism", (New York, Oxford University Press, 2002)

Stockhammer E., "Neoliberalism, income distribution and the causes of the crisis" School of Oriental and African Studies, Department of economics, Research on Money and Finance Discussion paper 19, (2010)

Stockhammer E., "Peripheral Europe's debt and German wages. The role of wage policy in the Euro Area" School of Oriental and African Studies, Department of economics, Research on Money and Finance Discussion paper 29, (2011)

Uho J., Paul J. and Febrero E., "Current Account Imbalances in the Monetary Union and the Great Recession: Causes and Policies", Paneconomicus, No.5, (2011) 